\title{
Analysis of Factor that Preferred by Customer in the Selection of Batara Savings Products at BTN Bank Branch Kamal
}

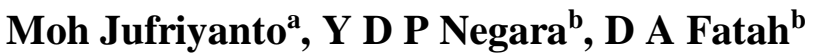 \\ aUniversity of Muhammadiyah Gresik, Gresik, Indonesia. \\ bDepartment of Informatics Engineering University of Trunojoyo Madura, Bangkalan, Indonesia
}

\section{A B S T R ACT}

Factor analysis is a statistical analysis that tries to find a relationship (interrelationship) between a number of variables are mutually independent from one another, so that it can be made one or several sets of variables are less than the amount of the initial variables. Researchers want to conduct research on the factors that necessitated the customer in product selection god savings deposits at Bank BTN Kamal, Bangkalan by factor analysis approach. From the results in getting that formed five factors capable of representing on the seventeenth of the variables used factor analysis conducted, five factors formed can be seen from the eigen value> 1 and pictures scree plot. Factors which is made by customers of Bank BTN in the selection of savings products Batara ie Employee Bank BTN responsive in serving, security transactions, procedures (and requirements) account opening Savings Batara easy was infested, Administration fee is low, and Employees of Bank BTN can give correct information and clear.

Keywords: factor analysis, factor, eigen value, scree plot,

Article History

Received 25 December 2019

Received in revised form 28 January $2020 \quad$ Accepted 15 April 2020

\section{Introduction}

The Bank as a provider of financial transaction services continues to make improvements to maintain its customers so that they always use the services of their products. Among the products that are often used are savings deposit services. Many banks appear that provide savings deposit services that have their respective superior features resulting in the bank continues to strive to improve and develop these features so that customer satisfaction is always fulfilled and able to compete with other bank savings products.

Bank Tabungan Negara (BTN) is an Indonesia focus in financial services. BTN is a bank that is quite well known by the society and wellknown because the bank has provided a variety of reliable products that are quite well known in the society.

Researchers surveyed about the customer factor is interested in choosing batara deposit savings products at BTN Bank. This research aims to determine the factors and maintain customer satisfaction to continue to use one of the BTN Bank products, namely Batara savings. Batara Savings is one of type of savings that is intended to cultivate the habit of saving and the savings can be used for companies or institutions.

On that problem, the researcher wants to researching customer priorities in selecting batara deposit savings products at Kamal BTN Bank, Bangkalan with a factor analysis approach. The use of factor analysis is in accordance with the desired objectives in the research. Factor analysis is a statistical analysis that tries to find relationships (interrelationship) between a number of variables that are independent of one another, so that one or several sets of variables can be made that are less than the number of initial variables. Collection of variables is called a factor and these factors still reflect the original variable. Therefore, in this study entitled "Analysis of Factor that Preferred by Customer in the Selection of Batara Savings Products at Kamal BTN Bank, Bangkalan" (case study in Kamal BTN Bank, Bangkalan)

\section{LITERATURE REVIEW}

\subsection{Service Quality}

According to Irawan (2003), the ServQual concept developed by Parasuraman, Zeithaml, and Berry is the concept most widely used by

* Corresponding author.Phone : +0-000-000-0000 ; fax: +0-000-000-0000.

E-mail address: author@institute.xxx . 
business people in terms of customer service. When the first concept of the service dimension was formulated there were ten dimensions, after that it was simplified to become five dimensions.

The explanation of the five dimensions are:

1. Tangible, a service cannot be seen, cannot be smelled, and cannot be touched, so the tangible aspect becomes an important rule of service.

2. Reliability, it is a dimension that measures the reliability of a company in providing services to its customers. This dimension is a very important dimension than the other four dimensions

3. Responsiveness, is the most dynamic dimension of service quality.

4. Assurance, it is a quality dimension related to the company's ability to instill trust and confidence in its customers. There are 4 aspects of this dimension, namely friendliness, competence, credibility, and security

5. Emphaty, dimensions that provide great opportunities to provide services that are suprise. Something that is not expected by the customer. Many ways you can do to please customers, for example: giving congratulations to customers on birthdays or holidays.

\subsection{Customer Satisfaction}

According to Kotler in 2000 (In Dewinta, 2013) satisfaction is someone's happy or disappointed feelings that arise after comparing someone's happy or disappointed perceptions that arise after comparing between their perceptions or impressions on the performance (results) of a product and its expectations. According to Supranto in 2001 (In satisfied. If they are not satisfied, they will leave the company and will become customers for competitors. Dewinta, 2013), customers must be

\subsection{Factor Analysis}

Yamin and Kurniawan in 2014 stated that factor analysis is one of the multivariate analysis families that aims to summarize or reduce the overall observational variables into several new variables or dimensions

New variables or dimensions that are formed are still able to present the main variables. In factor analysis there are two approaches, namely:

a. Exploratory factor analysis approach is an approach with many factors that will be formed if not determined in advance. b. The confirmatory factor analysis approach is the approach used if the number of factors that will be formed has been determined in advance.

According to Santoso (2014) states that the purpose of the factor analysis as explained below:

a. Summarization Data is identifying the relationship between variables by conducting a correlation test

b. Reduction Data is the process of making a new variable group called a factor to replace the factors of a number of certain variables.

Assumptions in Factor Analysis will explained below:

a. Correlation or correlation between variables is an independent variable that must be strong enough that is above 0.5 .

b. In a partial correlation that is the correlation between two variables by assuming the other variables are fixed, it must be small. Detecting partial correlation values can be done by looking at the value via the Anti Image Correlation option.

c. Testing all correlation matrices (correlations between variables) measured by the bartlet test of sphiericity or measure sampling adequacy (MSA). This test must allow for a significant correlation of some of the few variables used.

The assumption of normality of some of the variables formed or factors that occur should be fulfilled.

\section{RESEARCH METHODS}

The type of research used in this research is survey research Survey research is research that is used to get data from a particular place that is natural (not artificial), but for the treatment in data collection is done by several techniques such as: distributing questionnaires, tests, structured interviews and so on (Sugiyono2012, p. 5). The survey was conducted by interviewing and collecting data by giving questionnaires to Customers who own and use Batara Savings Bank BTN. The factors used in the study are as follows: Strategic location, the amount of interest earned, transaction security

Facilities obtained

a. Promotion carried out

b. BTNBank employees can provide information precisely and clearly

c. BTNBank employees are quick to respond (employees are alert and immediately serve)

d. Friendliness of service (good service, employees who are warm, welcoming and friendly

e. The bank accepts suggestions and criticisms

f. The appearance of the employees is tidy and good 
g. The environment of Bank BTN is neat, comfortable and clean

h. The procedures (ways and requirements) for opening a Batara Savings account are easy to fulfilled.

i. Reports and information are easily obtained

j. Administrative accuracy

k. Low administrative costs

1. Low administrative costs

m. Invite customers to get involved in an activity.

\subsection{Research Location and Time}

The location of researchis in Kamal BTN Bank (Bangkalan), the location of the Bank is in the area of Telang Village, Kamal Bangkalan.This location selection has received permission from the Kamal BTN Bank (Bangkalan Regency) to conduct research in its place. Location selection seems to be in accordance with the topic taken by researchers as many users of batara savings include students, lecturers and the community around Telang Village and surrounding areas.

\subsection{Amount of Data}

According to Rao Purba (quoted in Pranidana, 2009) the formula for taking samples with unknown population is explained below:

$$
4 n=\frac{Z^{2}}{4(m o e)^{2}}
$$

Where:

$\mathrm{n} \quad$ : amount of sample

$\mathrm{Z}$ : The level of confidence in determining the sample is $95 \%=$

1.96 Moe: Tolerable of margins error,

here set at $10 \%$ (determined by researchers)

so, the sample taken in this research is

$$
\begin{aligned}
& \mathrm{n}=(1,96)^{2} / 4 *\left(0,1^{2}\right) \\
& \mathrm{n}=3,8416 / 0,01 \\
& \mathrm{n}=96,04 \text { or } 96 \text { sample }
\end{aligned}
$$

so in this research 96 respondents would be taken. The sampling technique used is purposive sampling. This sampling technique is used based on the consideration of researchers only because researchers assume the desired elements already exist in the samples taken. Researchers took a sampling technique that is Purposive Sampling because respondents to be taken are people who know and use batara BTN Bank savings.

\section{RESULT AND DICUSSION}

\subsection{Descriptive Analysis of Respondents}

4.1.1 Gender
Following is the data processing seen from the characteristics of the respondents' genderthat used by researchers at the time of questionnaire distribution. The process is explained below :

\section{Gender}

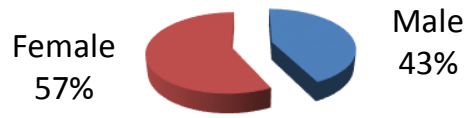

Fig 1. pie chart of Respondent's gender

In Figure 1 it can be seen that the percentage of respondents (customers) who participated in filling out the questionnaire is for male with a percentage of $43 \%$ and female with a percentage of $57 \%$.

\subsubsection{Test of Data Validity}

The results of the validity test of the research are as follows:

Hypothesis:

$\mathrm{H}_{0}$ : Data from the Answer item statement that invalid

$\mathrm{H}_{1}$ : Data from the Answer item statement that valid

Decision making:

If sig value $\leq 0,05$ then reject $\mathrm{H}_{0}$

If sig value $>0,05$ then receive $\mathrm{H}_{0}$

The table of validity testing results using SPSS software is as follows:

Table 1 Test of Data Validity

\begin{tabular}{cccccc}
\hline No & Statement & $\begin{array}{c}\text { Sig. Value }(2- \\
\text { tailed }\end{array}$ & $<>$ & $\begin{array}{c}\text { alpha }= \\
\mathbf{0 . 0 5}\end{array}$ & Information \\
\hline 1 & Statement_1 & 0 & $<$ & 0.05 & Valid \\
2 & Statement_2 & 0 & $<$ & 0.05 & Valid \\
3 & Statement_3 & 0 & $<$ & 0.05 & Valid \\
4 & Statement_4 & 0 & $<$ & 0.05 & Valid \\
5 & Statement_5 & 0 & $<$ & 0.05 & Valid \\
6 & Statement_6 & 0 & $<$ & 0.05 & Valid \\
7 & Statement_7 & 0 & $<$ & 0.05 & Valid \\
8 & Statement_8 & 0 & $<$ & 0.05 & Valid \\
9 & Statement_9 & 0 & $<$ & 0.05 & Valid \\
10 & Statement_10 & 0 & $<$ & 0.05 & Valid \\
11 & Statement_11 & 0 & $<$ & 0.05 & Valid \\
12 & Statement_12 & 0 & $<$ & 0.05 & Valid \\
13 & Statement_13 & 0 & $<$ & 0.05 & Valid \\
14 & Statement_14 & 0.001 & $<$ & 0.05 & Valid \\
15 & Statement_15 & 0 & $<$ & 0.05 & Valid \\
16 & Statement_16 & 0 & $<$ & 0.05 & Valid
\end{tabular}


From table 4.x it can be explained that all sig (2-tailed) values of all statements $<0.05$ then reject $\mathrm{H} 0$ means that the result data Answer item statement from the questionnaire distributed is valid

\subsubsection{Data Reliability Test}

The results of reliability testing using SPSS software are as follows: Hypothesis:

$$
\begin{aligned}
& \mathrm{H}_{0} \text { : Results data Answer statement items are not reliable } \\
& \mathrm{H}_{1} \text { : Results data Answer statement items are reliable Decision } \\
& \text { making: } \\
& \text { If the croncbach alpha value }>0.06 \text { then reject } \mathrm{H}_{0} \\
& \text { If the croncbach alpha value } \leq 0,06 \text { then receive } \mathrm{H}_{0}
\end{aligned}
$$

The reliability test table of the results of respondents' answers from the distribution of the questionnaire is as follows:

Table 2 data reliability test

\begin{tabular}{ccccc}
\hline $\begin{array}{c}\text { Number of } \\
\text { items }\end{array}$ & $\begin{array}{c}\text { Cronchbach } \\
\text { Alpha value }\end{array}$ & $\langle/\rangle$ & $\mathbf{0 . 6}$ & Information \\
\hline 17 & 0.823 & $>$ & 0.6 & Reliable \\
\hline
\end{tabular}

From the 2. table it can be seen that the Croncbach Alpha value is 0.823> 0.6 then reject $\mathrm{H}_{0}$ means that the results of the data Answer items are reliable statement

\subsection{Factor Analysis}

\subsubsection{Variable Selection Process}

\subsubsection{KMO Bartlett's test}

The results of the variable selection test with KMO Bartlett's test are as follows:

Hypothesis:

$\mathrm{H}_{0}$ : the variables have not been sufficient for further analysis

$\mathrm{H}_{0}$ : the variables have not been sufficient for further analysis

Decision making:

If the Sig value $\leq 0,05$ then reject $\mathrm{H}_{0}$

If the $\mathrm{Sig}$ value $>0,05$ then receive $\mathrm{H}_{0}$

Table 3 KMO Bartlett's test

\section{KMO and Bartlett's Test}

Kaiser-Meyer-Olkin Measure of Sampling Adequacy. Approx. Chi-Square

Bartlett's Test of Sphericity

df

Sig.
From Table 4.x, the KMO and Bartlett's test values are 0.697 with a sig value of $0<0.05$, so rejecting $\mathrm{H}_{0}$ means that the variables are sufficient for further analysis.

\subsubsection{MSA (Measure of Sampling Adequacy) Test}

Following are the results of testing the variable selection with MSA (Measure of Sampling Adequacy):

Decision making is taken from the MSA number ranging from 0 to 1 , with criteria:

- MSA = 1,these variables can be predicted without errors by other variables.

- MSA > 0.5,variables can still be predicted and can be analyzed further.

- MSA < 0.5,variables cannot be predicted and cannot be further analyzed, or taken out from other variables.

Table 4. MSA (Measure of Sampling Adequacy)

\begin{tabular}{ccc}
\hline No & Statement & MSA Value \\
\hline 1 & Statement_1 & 0.817 \\
2 & Statement_2 & 0.89 \\
3 & Statement_3 & 0.736 \\
4 & Statement_4 & 0.79 \\
5 & Statement_5 & 0.673 \\
6 & Statement_6 & 0.679 \\
7 & Statement_7 & 0.712 \\
8 & Statement_8 & 0.729 \\
9 & Statement_9 & 0.698 \\
10 & Statement_10 & 0.653 \\
11 & Statement_11 & 0.684 \\
12 & Statement_12 & 0.554 \\
13 & Statement_13 & 0.798 \\
14 & Statement_14 & 0.706 \\
15 & Statement_15 & 0.754 \\
16 & Statement_16 & 0.778 \\
17 & Statement_17 & 0.574 \\
\hline
\end{tabular}

From table 4. it can be seen that the MSA value of all statements> 0.5 and also almost close to 1 means that the variable can still be predicted and can be analyzed further. The conclusion from the selection of variables using MSA or KMO and Bartlett's test there is a high 0.697 relationship between the seventeen variables in this study that are 703.44 independent of each other, so that these variables can be grouped into 136 several factors that can represent these variables.

0.00 


\subsection{Scree Plot}

The following is a scree plot image that can also be used to explain the factors formed:

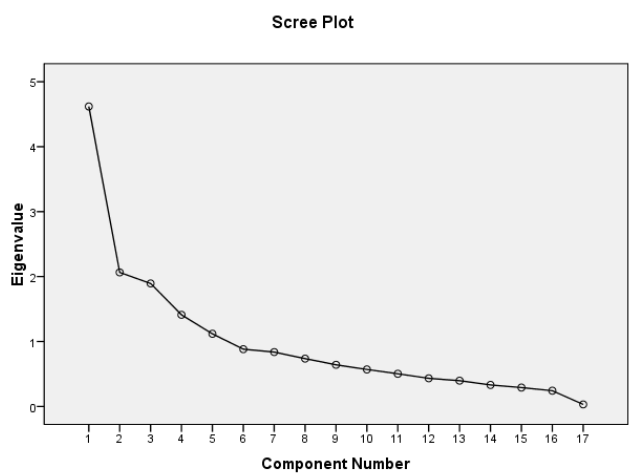

Gambar 2. Scree Plot

In Figure 4.x the scree plot explains that there is a decrease from one factor to another, for example from factor 1 there is a decrease to factor 2 , as well as for the next factor there is a decrease. The sixth factor is below the number 1 of the $\mathrm{Y}$ axis (eigen values) so that it shows that there are 5 factors that are best for summarizing the seventeen variables

\subsection{Determine what variables are included in the factors that have been formed through the factor rotation process}

The following is the next test that is determining what variables are included in the formed factor seen from the analysis of the factor loading values that have rotated the factors.By doing the factor rotation process will clarify the position of the variables in each factor and eliminate doubts in entering into the formed factor.The factor rotation process uses the varimax method. The test results using SPSS software are as follows :

Table 5. the result of the loading factor

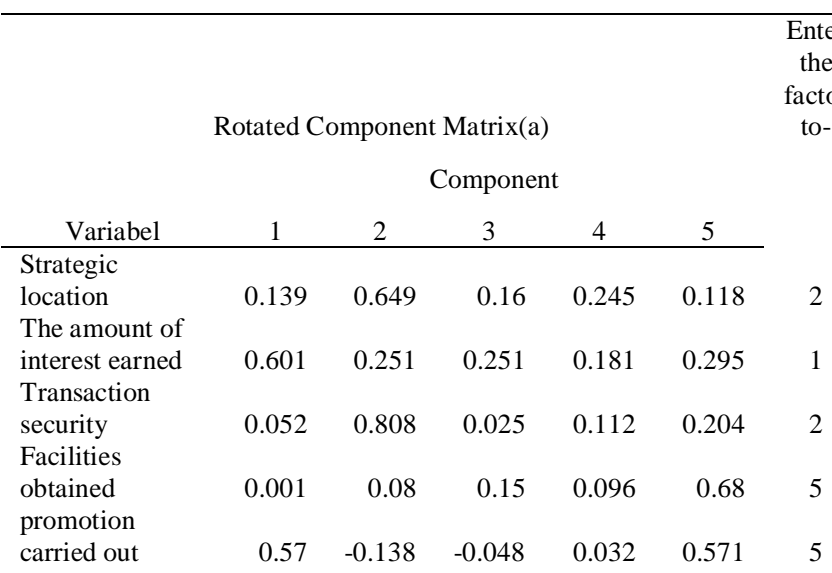

Bank BTN

employees can

provide

information

precisely and

clearly

$\begin{array}{llllll}0.118 & 0.283 & -0.028 & 0.105 & 0.71 & 5\end{array}$

Bank BTN

employees are

responsive in

serving

Friendliness of

service (good

service,

employees who

are warm,

welcoming and

friendly)

The bank

accepts

suggestions and

criticisms

The employee's

appearance is

neat and good

The

environment of

Bank BTN is

neat,

comfortable and

clean

the procedures

(ways and

requirements)

for opening a

Tabara Batara

account are

easily fulfilled

Reports and

information are

easily obtained

Administrative

accuracy

Low

administrative

costs

$0.713 \quad 0.229$

0

$-0.017$

0.097

$\begin{array}{llllll}0.703 & -0.336 & -0.016 & 0.143 & 0.235 & 1\end{array}$

$\begin{array}{llllll}0.024 & 0.637 & 0.158 & -0.037 & 0.337 & 2\end{array}$

$\begin{array}{lllll}0.668 & 0.075 & 0.413 & 0.189 & -0.299\end{array}$

$\begin{array}{llllll}0.616 & 0.186 & 0.376 & 0.2 & -0.32 & 1\end{array}$

$\begin{array}{llllll}0.155 & 0.096 & 0.934 & 0.089 & 0.08 & 3\end{array}$

$\begin{array}{llllll}0.098 & 0.308 & -0.2 & 0.625 & 0.048 & 4\end{array}$

$\begin{array}{llllll}0.012 & 0.576 & 0.101 & 0.161 & -0.22 & 2\end{array}$

$\begin{array}{llllll}0.089 & 0.127 & 0.212 & 0.821 & -0.021 & 4\end{array}$

Bank BTN's

concern for

customers

Invite customers

to get involved

in an activity $\begin{array}{llllll}0.115 & 0.221 & 0.921 & 0.084 & 0.107 & 3\end{array}$ $\begin{array}{llllll}0.131 & 0.034 & 0.164 & 0.766 & 0.2 & 4\end{array}$
From table 4.x it can be explained as the following example:

a. The variables included in the first factor are the amount of interest earned, BTN Bank employees are quick to respond in service, Friendliness service (good service, employees who are warm, and friendly), The appearance of the employees is tidy and good, the environment of BTN bank is tidy, comfortable and clean. 


\section{CONCLUSIONS AND SUGGESTIONS}

\subsection{CONCLUSIONS}

From the results of research conducted and calculations from results and discussion, it can be concluded that is:

a. Formed 5 factors that are able to represent the seventeen variables used based on the factor analysis conducted.

b. The factors that are prioritized by BTN Bank customers in the selection of Batara savings products are that BTN Bank employees are responsive in serving, transaction security, procedures (ways and requirements) of opening a Batara Savings account are easily fulfilled, administration costs are low, and BTNBank employees can provide information precisely and clear.

c. The five factors formed can be seen from the eigen value> 1 and the scree plot image

d. The value of communality explains the percentage of variance that is explained by the factors formed

e.

\subsection{SUGGESTION}

a. Give advice to BTN Bank to more improve the quality of its services by taking into account the factors that have been studied by researchers.

b. Can be used as an evaluation for BTNBank to evaluate the programs that have been given. c. Adding insight to the authors regarding multivariate analysis knowledge that can be used in research.

\section{REFERENCES}

[1] Dewinta.2013. Analysis of Factors that Customers Strive to Choose Tapenas Deposits (Case study of PT. Bank Negara Indonesia, Persero, Tbk Bogor Branch). Skripsi. Faculty of Economics and Management Bogor Agricultural University, Bogor.

[2] Irawan. H. 2003. Principle of Customer Satisfaction. Jakarta : PT Elex Media Komputindo

[3] Yamin.S, Kurniawan. H. 2014. SPSS Complete (The most complete statistical analysis technique with SPSS software). Jakarta : Salemba Infolex

[4] Pranidana, S, A. 2009. Analysis of Factors Affecting BCA Bank Customers' Interest in Using Klik-BCA. Skripsi. Faculty of Economics, Diponegoro University, Semarang.

[5] Rustiyaningsih, S. 2013. Widya Warta. Factors That Influence Entrepreneurship Intention. (02). 255-267.

[6] Santoso, S. 2014. Multivariate Statistics Concepts and Applications with SPSS Revised Edition. Jakarta : PT. Elex Media Computindo.

[7] Sugiyono. 2012. Quantitative, Qualitative, and R\&D Research Methods. Publisher :Alfabeta

[8] Widiastuti, A.2011. Data : Data Collection Techniques and Research Instruments. Yogyakarta State University. Yogyakarta, 